\title{
Recognition of Deferred Tax Assets Practices and Conservatism
}

\author{
Anna Azriati Che Azmi ${ }^{1}$ and Nurmazilah Mahzan
}

\begin{abstract}
The application of IAS 12 promotes a form of conservative accounting practice, especially concerning the recognition of deferred tax assets and liabilities. In this paper, we observe whether these conservative practices are also evident in Malaysia. We examine one book-tax difference that may have an impact on the adoption of IAS 12 in Malaysia. This rule concerns the treatment of losses or allowances under normal business operations (category I) and those types of business that are granted tax incentives (category II). We propose that companies are more conservative if they recognise less deferred tax assets due to unabsorbed tax losses and allowances and vice versa. We also identify whether any distinct patterns exist among industries and auditor type with the recognition of deferred tax assets. Using descriptive and inferential statistics, we analyse the recognition of deferred tax assets practices for 880 public listed companies. Two main conclusions can be made from the findings. Firstly, Malaysian companies reflect a high degree of conservatism in their practices of adopting FRS 112. Secondly, a further analysis shows that companies in the Plantation, Properties and Construction Industry show significant differences in their level of conservatism while Big-4 auditors also show higher levels of conservatism.
\end{abstract}

Keywords: Deferred tax assets, Conservatism, IAS 12, Malaysia

\section{Introduction}

Most of the countries around the world are moving towards convergence with the International Financial Reporting Standards (IFRS). The benefits of a global financial reporting framework are numerous and include greater comparability of financial information for investors, greater willingness on the part of investors to invest across borders, lower cost of capital, more efficient allocation of resources, and higher economic growth. Malaysia, being part of the competitive global economy, has also responded to the pressure of intense global economic

1 Corresponding author: Dr Anna Azriati Che Azmi is a Senior Lecturer at the Faculty of Business \& Accountancy, University of Malaya, email:annaazriati@um.edu.my. Dr Nurmazilah Mahzan is a Senior Lecturer at the Faculty of Business \& Accountancy, University of Malaya. 
competition by setting the deadline for full convergence of 1st January 2012. It is believed that the branding of "IFRS Compliant" will help Malaysian Companies maintain their global recognition and competitiveness (Malaysian Institute of Accountants, 2008). This study adds to the literature that observes the impact of IFRS convergence on Malaysian financial reporting practices, specifically, and emerging economies, generally.

IFRS, which are principles based, allows for judgment under conditions of uncertainty (Schipper, 2003; Sunder, 2009). Under conditions of uncertainty, conservatism is a common concept used by accounting preparers. In our study we define conservatism 'on the basis of balance sheet valuation' (Hellman, 2008, p. 77). This means defining conservatism as choosing accounting methods and estimates that give relatively low book values of net assets (Hellman, 2008; Penman \& Zhang, 2002). Watts (2003a) indicates that the relationship between taxation and financial reporting leads to conservatism in financial reporting practices. The incentive for firms to conform reported accounting income to taxable income, in some instances, could lead to the understatement of net assets (Shackelford \& Shevlin, 2001). Degrees of conservatism also differ among countries. Ball, Robin, and Wu (2003) find that the level of conservatism in financial reporting of Asian countries, such as Malaysia, is more similar to code law countries than common law countries, such as the UK. This is peculiar, as Malaysia is a commonwealth country. This study also adds to the existing literature that examines how conservatism practices exist due to the interaction between taxation and financial reporting practices.

Thus, the main aim of this paper is to observe whether the current practices of companies concerning the recognition of deferred tax assets due to unabsorbed tax losses and capital allowances from normal businesses and businesses that are granted tax incentives are reflections of the conservatism principles. We also examine patterns that might emerge due to the industry characteristic and auditor type with the recognition of practices for these deferred tax assets. Our analysis uses descriptive and inferential statistics and we focus on the deferred tax practices of Malaysian companies in 2008, a year after IAS 12 was adopted in Malaysia. Consistent with Ball et al. (2003), our observations show that Malaysian companies are practicing conservative accounting practices under uncertainty. This pattern is common across industries. For auditor type, companies with Big 4 auditors show higher levels of conservatism.

\section{Conservatism and IAS 12}

There are many definitions of conservatism in the literature. Conservatism is one way of dealing with uncertainty in financial reporting (Hämäläinen, 2011). Conservatism is defined by Basu (1997, p. 7) as 'denoting accountants' tendency to require a higher degree of verification to recognize good news as gains than to recognize bad news as losses'. In this paper, we adopt the definition prescribed 
by Hellman (2008). Hellman (2008) defines conservatism on the basis of balance sheet valuation, which he classifies into two categories: consistent and temporary conservatism. Consistent conservatism refers to the consistent application of the conservatism principle across different time periods for similar transactions. While temporary conservatism is a temporary application of the conservatism principle, such as the creation of reserves or provisions that may reverse in later years. The lack of recognition of deferred tax assets due to loss carried forward, as prescribed by para 34-37 of IAS 12 (1996), is an example of temporary conservatism (Hellman, 2008). In our paper, we examine this form of temporary conservatism.

Hellman (2008) argues that temporary conservatism, such as that in IAS 12, is still practiced by account preparers and should not be disregarded in favour of neutrality by accounting standard setters. In this study, we present the literature that identifies auditor type, industry and even country characteristics as being influential in promoting different levels of conservatism among companies. Hämäläinen (2011) identifies two sources of accounting conservatism: accounting standards and incentives of managers and auditors. Nelson (2003, p. 101) highlights that conservatism practices are as important as accounting 'standards that are imprecise enough to offer no safe harbours' to constrain auditors from aggressive reporting. Conservatism is also observed as an important concept in the behavioural studies of auditors. Similarly, Ball et al. (2003, p. 236) find that:

"accounting standards and preparer incentives in these countries [Malaysia is one of the countries under their observation] interact to produce generally low quality financial reporting, consistent with the hypothesis that reporting quality ultimately is determined by the underlying economic and political factors influencing managers' and auditors' incentives, and not by accounting standards per se."

In another study, Jamal and Tan (2010) find that auditors are able to influence managers of companies to be less conservative in selecting the classification of leases as operating or finance lease. Different auditor type also influences conservatism in accounting practices. Several studies (such as Piot, Dumontier and Janin, 2011; Kim, Chung and Firth, 2003) find that less conservative accounting practices are more apparent with Big 4 auditors.

Some literature (Gaeremynck \& Van De Gucht, 2004; Iatridis, 2011) focuses on country and company characteristics, such as industry and size of company, to study the deferred tax practices and degree of conservatism. Particular industries may exhibit more conservative accounting practices due to certain rules in the accounting standards. Chandra, Wasley, and Waymire (2004) find that firms in the technology sector exhibit a higher level of income conservatism due to the accounting rules that require expensing of research and development costs. Pae, Thorton, and Welker (2005) also suggest that the degree 
of earnings conservatism also differs across countries due to varying institutions and regulatory mechanisms. Ball et al. (2003) find that the degree of conservatism in four Asian countries is similar to code law countries despite their common law heritage. They attribute this to the political influence concerning financial reporting and information asymmetry that is resolved through private rather than public channels of communication (Watts, 2003b). Salehi and Ghorbani (2011) find no evidence of earnings conservatism for companies listed on the Tehran exchange. They attribute this to the significant government ownership of listed companies on the Tehran exchange.

In this section, we argue that conservative accounting practices due to the application of accounting standards are evident among companies in different industries and auditor type. Malaysia is also a country that exhibits a high degree of conservatism in its financial reporting practices. In the next section, we provide a brief background on the application of IAS 12 in Malaysia and its implications for the book-tax differences.

\section{Malaysia and IAS 12}

The Malaysian Accounting Standards Board (MASB), the body responsible for the accounting standard setting process in Malaysia, has also outlined a schematic roadmap towards achieving the goal of full "IFRS Compliance" by 2012, which effectively means that all IFRS have to be adopted and used by public companies by 2012 . However, there is bound to be an implementation issue arising from different legal and regulatory frameworks. One of the prominent areas is taxation in which Malaysian tax legislation contains salient features not available in other jurisdictions. For example, the promotion of investment mechanisms, such as investment tax allowance and reinvestment allowance. From the financial reporting perspective, the adoption of the IASB based standard on Income Tax FRS 112 (similar to IAS 12) - in 2007, is one of the steps towards full convergence. FRS 112, which replaced FRS 112 2004, prescribes that companies recognise any book-tax difference using the full provision method. Prior to the adoption of FRS 112, para 36 of FRS 1122004 prohibited any unutilised reinvestment allowance to be recognised as temporary differences.

Since FRS 112 is a standard issued by MASB that outlines the recognition and disclosure rules for book-tax differences, the impact of certain tax rules in Malaysia on accounting practices will have implications on book-tax differences. Similar to IAS 12, FRS 112 prohibits the initial recognition of an asset or liability in most cases. However, companies may recognise deferred tax assets for unused tax losses and tax credits 'to the extent that it is probable that future taxable profit will be available against which the unused tax losses and unused tax credits can be utilised' (para 34). This rule is controversial in Malaysia because of the existence of Malaysian tax incentives, such as reinvestment allowances (RA) and investment tax allowances (ITA). These incentives along with the 
interpretation of para 34 of FRS 112 allow companies to additionally recognise tax allowances and losses as deferred tax assets. The recognition of deferred tax assets has significant effects on the balance sheet. For example, Air Asia Berhad, a Malaysian listed company reported a book-tax difference that is nearly six times the amount declared under FRS 112. In its annual report, Air Asia recognises unutilised reinvestment allowances as tax credits. This adopted definition of tax credits is acceptable because FRS 112 does not define tax credits.

MASB, through its staff paper, acknowledges the different accounting practices adopted by companies to define tax credits. There are three approaches for recognising these unutilised RA and ITA: the tax credit approach, the government grant approach and the tax based approach. By recognising unutilised RA and ITA under the first and second approach, the deferred tax assets could be recognised. The tax based approach, however, means that deferred tax assets should not be recognised for any unutilised RA and ITA. Such an understanding, however, is not fully supported by the local office of the Big 4 accounting firms on the appropriate treatment for these unutilised allowances. MASB indicates that the unutilised RA and ITA are not tax credits, thus rejecting the first approach while one of the Big 4 firms is of the opinion that these unutilised allowances are tax credits.

Additionally, if the unutilised ITA/RA are treated as tax credits, this practise could mean that other types of investment tax credits also qualify as tax credits. There are other forms of investment incentives in Malaysia, particularly pioneer status, increased allowance for exports, which apply similar principles of reducing taxable profit of companies as that of RA/ITA. All of these investment incentives offer unused allowances or losses to be offset against future taxable profit. However, the main distinction between these incentives is based on their industry characteristics. Generally, companies in the manufacturing and agriculture industries, which have incurred huge capital expenditure, qualify for RA or ITA (Inland Revenue Board of Malaysia, 2012); companies in similar industries with minimal capital expenditure but that incur losses would opt for pioneer status (Inland Revenue Board of Malaysia, 2010); companies which are in the export industry would apply for allowances for increased exports (AIE) (Inland Revenue Board of Malaysia, 2013). Thus, the book-tax differences between the accounting treatments of the mentioned investment incentives should be similar to RA/ITA. If unutilised RA/ITA could result in temporary differences; these 'unutilised allowances' from other investment incentives should also be considered as temporary differences up to the amount that there is future taxable profit to offset these allowances.

The current tax regulation grants tax incentives to many Malaysian companies. These tax incentives result in unabsorbed tax losses for many Malaysian companies. This would lead to the practice of recognising more deferred tax assets. However, our results show that Malaysian companies will be 
more conservative and reluctant to recognise deferred tax assets in their balance sheet. Our results also show that these conservative practices will be different among companies in different industries and auditor type. The following section outlines our research methodology.

\section{Research Methodology}

To identify temporary conservative practices in IAS 12, we followed the method in Hellman (2008). We extracted information related to the application of para 34-36 of FRS 112 (equivalent to para 34-36 of IAS 12) in relation to the observed tax incentives identified in section 3 . Only 880 companies provided disclosure on the above items, thus, only these companies were used for the analysis. Our data collection and analysis methods are presented as follows. Firstly, data on the recognition of deferred tax assets were hand collected from the annual report 2008 of all companies listed on Bursa Malaysia. We chose 2008, because, by this year, all Malaysian listed companies would have adopted FRS 112. We classified unabsorbed tax losses and allowances into two categories. For unabsorbed tax losses and allowances arising from normal businesses, we identified it as category I. For unabsorbed tax losses and allowances arising from businesses that were granted tax incentives from reinvestment allowances/investment allowances (RA/ ITA), pioneer losses and allowance for increased exports (AIE), we identified it as category II. We predicted that companies will rarely recognise category II items as deferred tax assets compared to the recognition of category II due to conservatism. In respect of the treatment of tax incentives (category II), particularly reinvestment allowances/investment allowances (RA/ITA), pioneer losses and allowance for increased exports (AIE), the following items were collected:

- Deferred tax assets recognised due to unabsorbed tax losses and capital allowances

- Unrecognised unabsorbed tax losses and capital allowances

- Deferred tax assets recognised due to any unutilised reinvestment allowances, pioneer and allowances for increased export

- Unrecognised unutilised reinvestment allowances, pioneer and allowances for increased export

Secondly, our study also observed the patterns of companies' characteristics and auditors' characteristics in the recognition of deferred tax assets. For this, we collected the type of industry, as identified by Bursa Malaysia and the names of auditors for the 880 companies. We then classified auditors into two types: Big 4 and non-Big 4. Finally, we performed ANOVA test and t-test to determine whether there were any significant differences in the practice or recognition of deferred tax assets among industries and auditor type, respectively. Our results are presented in the next section. 


\section{Research Results}

The following section presents the profile of our sample and their general practices concerning the recognition of deferred tax assets. This is followed by the analysis based on industry and auditor type.

\subsection{Profile of companies}

A total of 880 companies listed on Bursa Malaysia were chosen for this analysis, their profiles are presented in Figure 1. These companies were chosen because they are the companies that provide disclosure on deferred tax assets regarding the following items: (1) unabsorbed tax losses and capital allowances, and (2) unutilised reinvestment allowances, pioneer losses and/or allowances for increased export.

Table 1: Profile of companies

\begin{tabular}{|c|c|c|c|c|c|}
\hline Industry & $\mathrm{N}$ & $\%$ & Total revenue Year 2008 & $\mathrm{~N}$ & $\%$ \\
\hline Closed End Fundbbs & 1 & 0.1 & less than RM200 million & 493 & 56.0 \\
\hline Construction & 49 & 5.6 & RM200 million - RM400 million & 155 & 17.6 \\
\hline Consumer Products & 149 & 16.9 & RM400 million - 600 million & 63 & 7.2 \\
\hline Finance & 8 & 0.9 & 600 million - 800 million & 36 & 4.1 \\
\hline Hotels & 4 & 0.5 & 800 million - 1,000 million & 22 & 2.5 \\
\hline Industrial Products & 264 & 30.0 & Above 1,000 million & 111 & 12.6 \\
\hline IPC & 6 & 0.7 & Total & 880 & 100.0 \\
\hline Mining & 1 & 0.1 & & & \\
\hline Other & 13 & 1.5 & Total Assets Year 2008 & $\mathrm{~N}$ & $\%$ \\
\hline Plantation & 35 & 4.0 & less than RM200 million & 363 & 41.3 \\
\hline Properties & 76 & 8.6 & RM200 million - RM400 million & 163 & 18.5 \\
\hline Reit & 12 & 1.4 & RM400 million - 600 million & 81 & 9.2 \\
\hline Technology & 93 & 10.6 & 600 million - 800 million & 67 & 7.6 \\
\hline Trading \& Service & 169 & 19.2 & 800 million - 1,000 million & 39 & 4.4 \\
\hline Total & 880 & 100.0 & Above 1,000 million & 167 & 19.0 \\
\hline & Total & 880 & 100.0 \\
\hline Big 4 audit firms & $\mathrm{N}$ & $\%$ & & & \\
\hline PWC & 70 & 14.1 & Big 4 versus non-big 4 & $\mathrm{~N}$ & $\%$ \\
\hline KPMG & 132 & 26.7 & Non-Big 4 & 385 & 43.8 \\
\hline EY & 233 & 47.1 & Big 4 & 495 & 56.3 \\
\hline Deloitte & 60 & 12.1 & Total & 880 & 100.0 \\
\hline Total & 495 & 100.0 & & & \\
\hline
\end{tabular}


The majority of these companies come from three of the following industries: Industrial products (30\%), Trading and Service (19.2\%) and Consumer Products $(16.9 \%)$. Based on the value of assets disclosed, nearly half of these companies, $41.3 \%$, have assets of less than RM200 million. Similarly, nearly 56\% earned revenue of less than RM200 million for the year 2008. Of these companies 56\% were audited by the Big 4 audit firms while the rest (i.e. $43.8 \%$ ) were audited by non-Big 4 audit firms. Most of the companies that were audited by the Big 4 audit firms were audited by Ernst and Young (47.1\%).

\subsection{Recognition of deferred tax assets}

The main aim of this study is to observe the conservatism that may be reflected in the practice of recognising deferred tax assets. In this section, observations are divided into two categories. Category I deals with the recognition of deferred tax assets for unabsorbed tax losses and capital allowances. Category II deals with recognition of deferred tax assets for unutilised reinvestment allowances, pioneer losses and allowances for increased exports.

Figure 1 presents the recognition rate for category I deferred tax assets. We expect to find that more companies are reluctant to recognise deferred tax assets under cases of uncertainty due to conservatism, which, to a certain extent, is reflected in practice. Most companies chose not to recognise deferred tax assets $(n=189)$ or to recognise the deferred tax asset at minimal level, which is $1 \%-20 \%$ $(n=192)$. Next to these two practices, Malaysian companies prefer to recognise deferred tax assets at $100 \%(n=111)$. Overall, Malaysian companies prefer to recognise deferred tax assets at minimal or the maximum end. This pattern of practice is also observable across industries and auditor type, this is discussed in the following sections.

Figure 1 Category I: Percentage of recognition of deferred tax assets

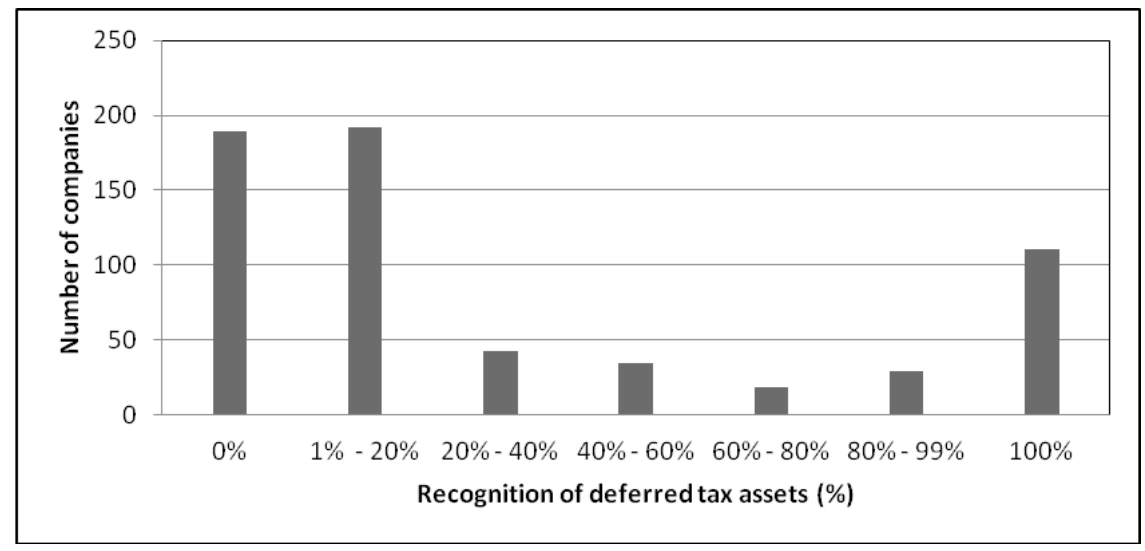


For category II, we expect to see a higher degree of conservatism, which is reflected in Figure 2, which presents the recognition rate for category II deferred tax assets. We see a higher degree of conservatism when (1) most companies $(n=65)$ chose not to recognise deferred tax assets under this category; (2) in comparison to Figure 1, Figure 2 shows that companies are less willing to recognise deferred tax assets under category II. This finding could possibly be a reflection of the uncertainties that surround companies on how para 34-36 of FRS 112, as explained in section 3, could be applied to the recognition of deferred tax assets. Following from the conservatism principle, under these uncertainties, many companies prefer not to recognise deferred tax assets under category II.

Figure 2 Category II: Percentage of recognition of deferred tax assets

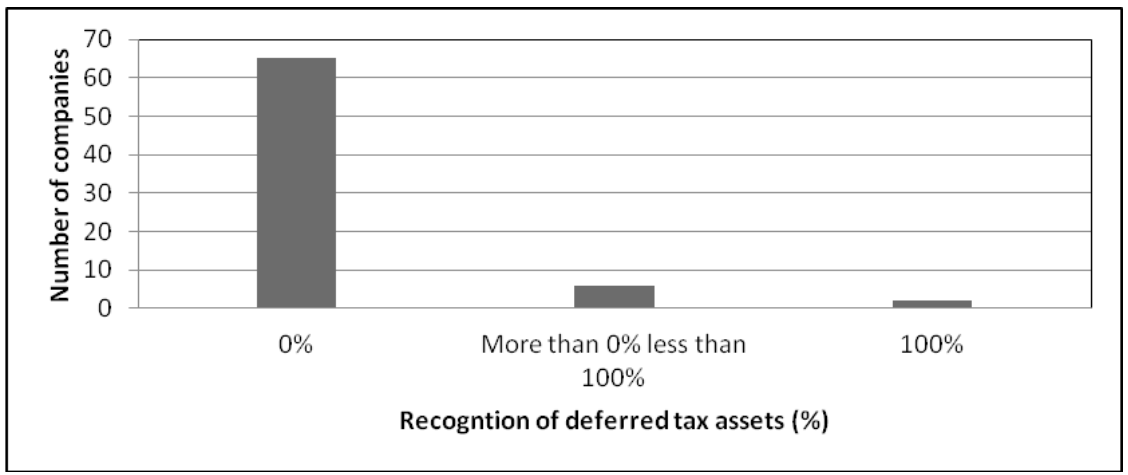

\subsubsection{Recognition of deferred tax assets by industries}

Figure 3 shows that, in most industries, companies prefer to recognise less than $20 \%$ of deferred tax assets under category I. Although, we also see that some industries do recognise deferred tax assets at $100 \%$, we find that there are more companies in the IPC and Plantation industries that would recognise deferred tax assets at $100 \%$ than any other percentage of recognition.

A one-way between-groups analysis of variance was conducted to explore the impact of industry on the percentage of recognition of deferred tax assets. There are 11 industries determined by Bursa Malaysia (i.e. REIT was excluded from the analysis because it has only one company in that particular industry). There was a statistically significant difference at the $p<.001$ level in the percentage of deferred tax assets recognised for the 11 industries for category I: $F(11,606)=$ $2.70, \mathrm{p}<.001$. Post-hoc comparisons using the Tukey test indicated that the mean score for Plantation $(\mathrm{M}=52.81, \mathrm{SD}=42.56)$ was significantly different from Properties $(\mathrm{M}=21.49, \mathrm{SD}=35.92)$ and Construction $(\mathrm{M}=18.52, \mathrm{SD}=29.63)$. Other industries did not differ significantly from each other. 
Figure 3 Category I: Percentage of recognition of deferred tax assets (DTA) based on industry

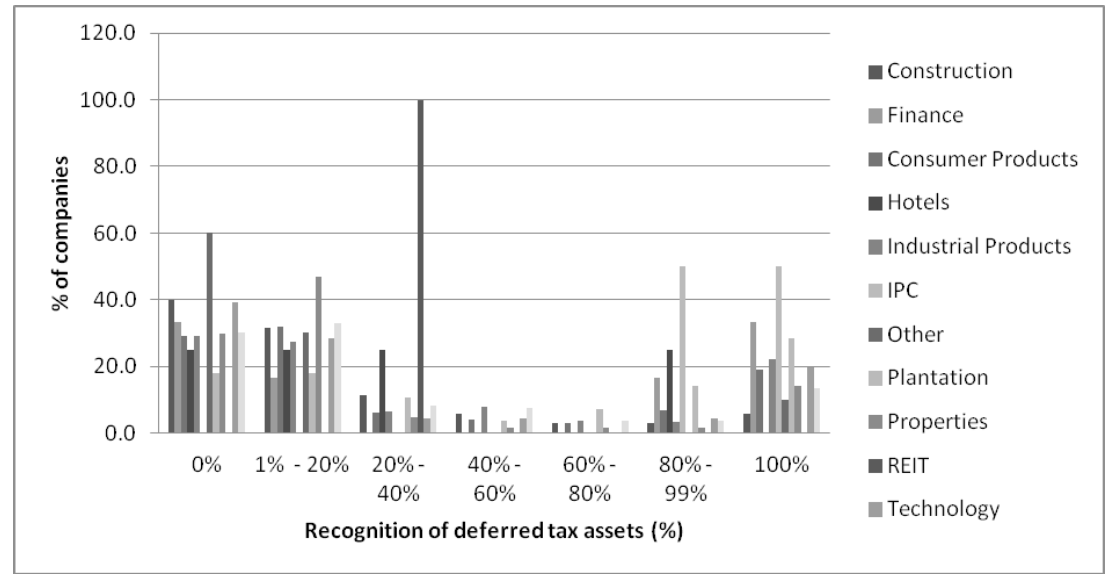

Figure 4 Category II: Percentage of recognition of deferred tax assets based on industry

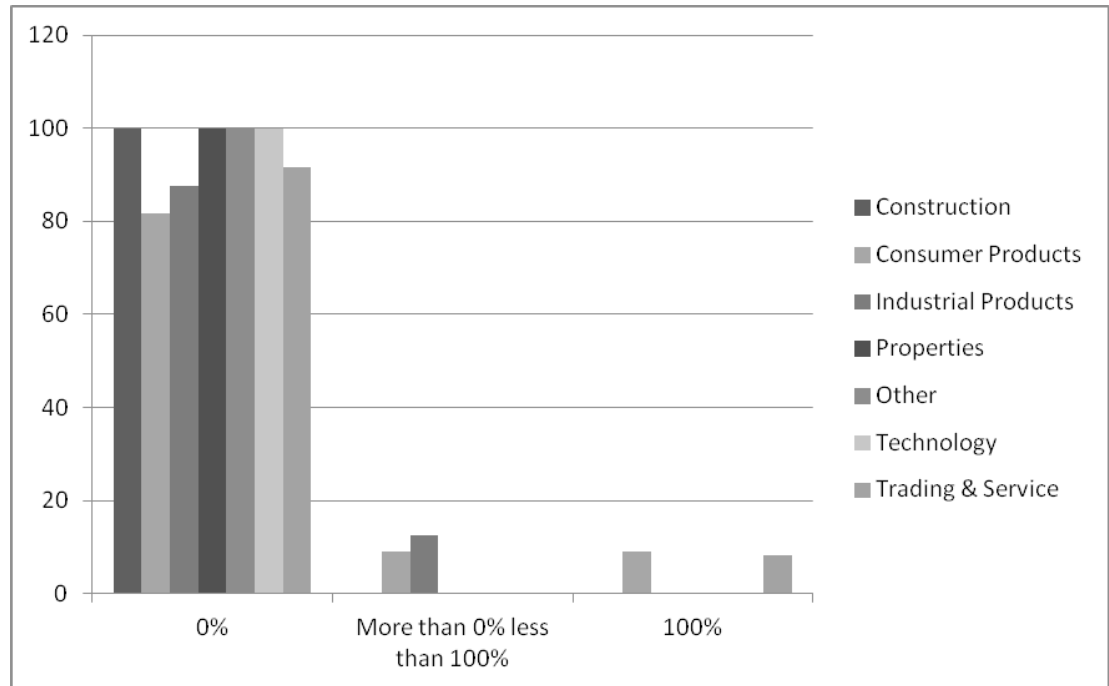

Figure 4 shows that companies in seven industries have category II items, reflecting a more conservative approach. All industries prefer not to recognise their deferred tax assets under this category. A one-way between-groups analysis of variance was conducted to explore the impact of industries on percentage of recognition of deferred tax assets. There was no statistically significant difference in the percentage of deferred tax assets recognised for the seven industries in category II: $\mathrm{F}(7,71)=.18, \mathrm{p}=.989$. 


\subsubsection{Recognition of deferred tax assets based on auditors' characteristics}

Some studies (e.g. Jamal \& Tan, 2010) have observed that auditor type influences companies in their accounting choice. Figure 5 presents the recognition rate for category I deferred tax assets by audit firms that are classified as Big 4 and non-Big 4. Companies audited by the non-Big 4 are more willing to recognise deferred tax assets at $100 \%$. Companies audited by the Big 4 are seen as more conservative as they prefer to recognise deferred tax assets at $60 \%$ or less. We could conclude that companies audited by non-Big 4 are less conservative than those audited by Big 4 audit firms. Overall, both groups prefer to recognise deferred tax assets into 3 common categories: (1) no recognition of deferred tax assets, (2) minimal recognition (i.e. 1\%-20\%) of deferred tax assets and (3) 100\% recognition of deferred tax assets. An Independent-samples t-test was conducted to compare the percentage of recognition of deferred tax assets for non-Big 4 and Big 4 . There was no significant difference in scores for non-Big $4(\mathrm{M}=33.17, \mathrm{SD}=41.45)$ and Big 4, $\mathrm{M}=30.13, \mathrm{SD}=38.87$; $\mathrm{t}(465.08)=0.91, \mathrm{p}=.37$ (two tailed).

Figure 5 Category I: Percentage of recognition of deferred tax assets based on Big 4 versus non-Big 4 audit firms

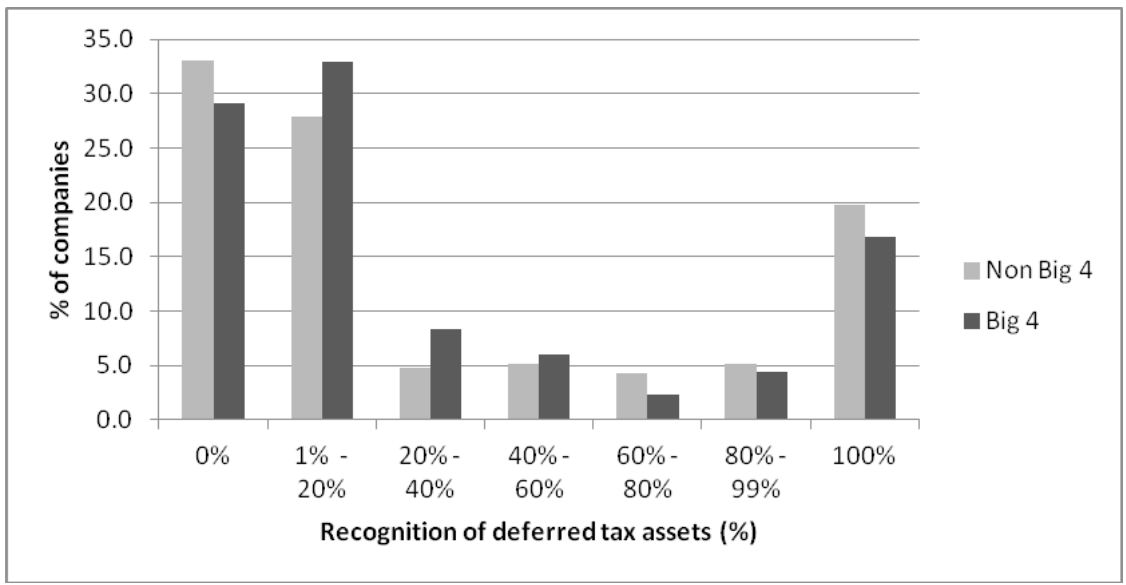

Figure 6 presents the recognition rate for category II deferred tax assets by audit firms, which are classified as Big 4 and non-Big 4. Overall, the companies show similar pattern of conservative practices in recognising deferred tax assets. For both groups, not recognising deferred tax assets is the most preferred choice. An Independent-samples t-test was conducted to compare the percentage of recognition of deferred tax assets for non-Big 4 and Big 4. There was no significant difference in scores for non-Big $4(\mathrm{M}=, 5.64, \mathrm{SD}=22.9)$ and $\operatorname{Big} 4, \mathrm{M}=5.25, \mathrm{SD}$ $=19.94 ; \mathrm{t}(77)=27.19, \mathrm{p}=.943$ (two tailed). 
Figure 6 Category II: Percentage of recognition of deferred tax assets based on Big 4 versus non-Big 4 audit firms

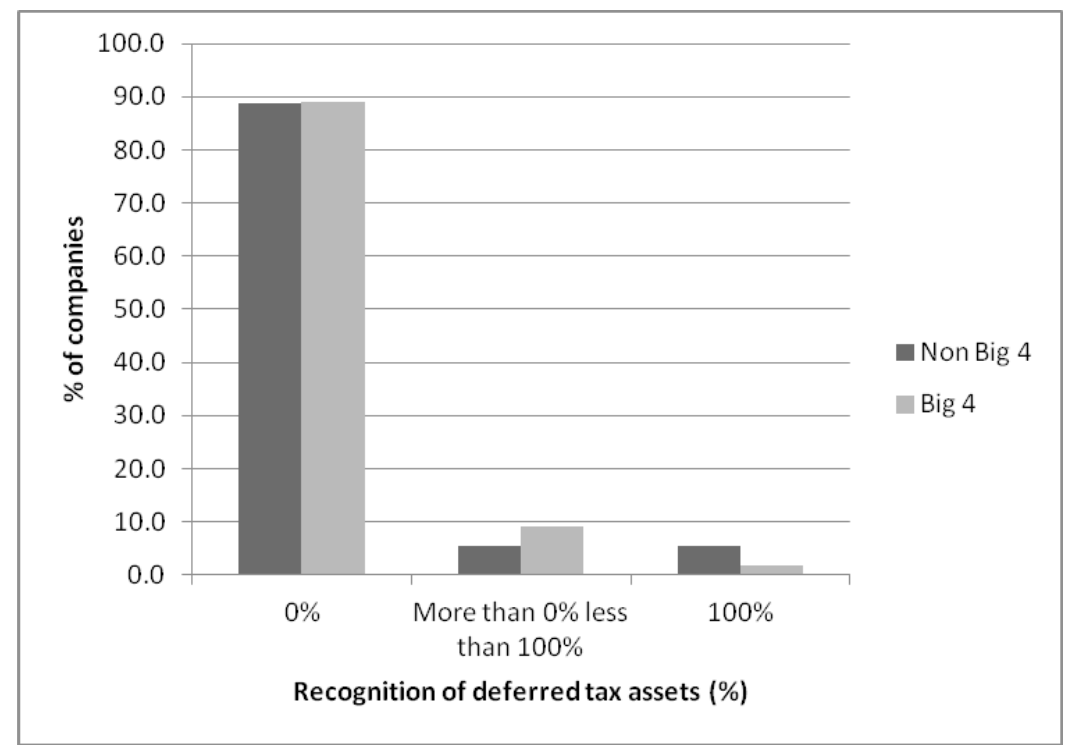

\section{Discussion, Implications and Future research}

Based on the findings of this study, several conclusions could be made. Firstly, the rate of recognition of deferred tax assets for category I is more diversified than category II. More companies are willing to recognise deferred tax at different degrees of recognition for category I whereas for category II, more companies prefer not to recognise deferred tax assets. Secondly, companies are more conservative in recognising deferred tax assets for both categories as the most common practice for companies is not to recognise deferred tax assets at all. These findings are consistent with Hellman (2008) who suggests that temporary conservative practices are evident in IAS 12. Thirdly, conservative practices differ based on industry. This could possibly be due to the amount of tax incentives that these industries may have. Fourthly, to a certain degree, auditors' characteristics do influence the conservative practices among companies. Companies with NonBig 4 auditors show less conservative practices in the application of IAS 12 than Big 4. Our findings support the earnings quality hypothesis whereby the Big 4 has the opportunities to import Anglo Saxon practices, which have higher levels of conservatism (Piot, Dumontier, \& Janin, 2011).

This study makes several contributions to the research concerning the application of conservatism for different accounting standards and countries. Research in this area assists in identifying practices that promote earnings management (Dhaliwal, Gleason, \& Mills, 2004; Phillips, Pincus, \& Rego, 2003). Watts (2003b) suggests that future research on conservatism could investigate the behaviour of accounting regulators in encouraging aspects of conservative 
accounting practice among preparers. Thus, a practical implication of this study is to create awareness for standard setters, such as the Malaysian Accounting Standards Board in handling issues of uncertainty in the application of a principles based standard, such as the IFRS. Our results show that conservative accounting practices exist among Malaysian companies, especially in areas where there are ambiguities, such as the application of para 34-36 of IAS 12. This study also adds to the existing literature on emerging economies and conservative accounting practices. Malaysia does show a high degree of conservatism, especially in the application of IAS 12. Future research could extend this study in several areas. A potential study is to observe the effect of current conservative practices in the implementation of IAS 12 on the behaviour of investors, creditors and other stakeholders. Another potential study is to identify the differences between those companies enjoying tax incentives and those that do not apply IAS 12.

\section{References}

Air Asia Berhad. (2006). Annual Report.

Ball, R., Robin, A., \& Wu, J. (2003). Incentives Versus Standards: Properties of Accounting Income in four East Asian Countries, and Implications for Acceptance of IAS. Journal of Accounting and Economics, 36(1-3), 235270.

Basu, S. (1997). The conservatism principle and the asymmetric timeliness of earnings. Journal of Accounting and Economics, 24(1), 3-37.

Chandra, U., Wasley, C. E., \& Waymire, G. B. (2004). Income Conservatism in the U.S. Technology Sector. Simon School Working Paper No. FR 04-01. doi: http://dx.doi.org/10.2139/ssrn.485064

Dhaliwal, D. S., Gleason, C. A., \& Mills, L. F. (2004). Last-Chance Earnings Management: Using the Tax Expense to Meet Analysts' Forecasts. Contemporary Accounting Research, 21( 2), 431-459.

Gaeremynck, A., \& Van De Gucht, L. (2004). The Recognition and Timing of Deferred Tax Liabilities. Journal of Business and Finance and Accounting, $31(7 \& 8), 985-1014$.

Hämäläinen, S. (2011). The effect of institutional settings on accounting conservatism - Empirical evidence from the Nordic countries and the transitional economies of Europe. (Doctor of Philosophy), Lappeenrannan Teknillinen Yliopisto.

Hellman, N. (2008). Accounting Conservatism under IFRS. Accounting in Europe, 5(2), 71-100.

Iatridis, G. E. (2011). Accounting Disclosures, Accounting Quality and Conditional and Unconditional Conservatism. International Review of Financial Analysis, 20 (2011), 88-102. 
Inland Revenue Board of Malaysia. (2010). Pioneer Status. Retrieved 20 February 2013, from http://www.hasil.gov.my/goindex.php?kump=5\&sk $\underline{\mathrm{um}}=5$ \&posi $=6 \&$ unit $=1 \&$ sequ $=3$

Inland Revenue Board of Malaysia. (2012). Reinvestment Allowances Public Ruling No 6/2012: Inland Revenue Board of Malaysia.

Inland Revenue Board of Malaysia. (2013). Deductions for Promotion of Exports Public Ruling No. 1/2013: Inland Revenue Board Of Malaysia.

Jamal, K., \& Tan, H. T. (2010). Joint Effects of Principles-Based versus Rulesbased Standards and Auditor Type in Constraining financial Managers' Aggressive Reporting. The Accounting Review, 85(4), 1325-1346.

Malaysian Accounting Standards Board. (2004). FRS 112 Income Taxes. Kuala Lumpur: Malaysian Accounting Standards Board.

Malaysian Accounting Standards Board. (2006). FRS 112 Income Taxes. Kuala Lumpur: Malaysian Accounting Standards Board.

Malaysian Institute of Accountants. (2008). Full Convergence with IFRS in 2012. Accountants Today, 21, 22-23.

Nelson, M. W. (2003). Behavioral evidence on the effects of principles- and rules-based standards. Accounting Horizons, 17(1), 91-104.

Pae, J., Thorton, D. B., \& Welker, M. (2005). The Link between Eamings Conservatism and the Price-to-Book Ratio. Contemporary Accounting Research, 22(3), 693-717.

Penman, S. H., \& Zhang, X.-J. (2002). Accounting conservatism and the quality of earnings, and stockreturns The Accounting Review, 77(April), 237-264.

Phillips, J., Pincus, M., \& Rego, S. O. (2003). Earnings management: New evidence based on deferred tax expense. The Accounting Review, 78(2), 491-521.

Piot, C., Dumontier, P., \& Janin, R. (2011). IFRS Consequences on Accounting Conservatism Within Europe: The Role of Big 4 Auditors (Publication no. http://dx.doi.org/10.2139/ssrn.1754504). http://ssrn.com/abstract=1754504

Salehi, M., \& Ghorbani, B. (2011). An Investigation of Relationship between Earnings Conservatism and Price to Book Ratio Based on Basu's Method. International Journal of Business and Development Studies, 3(1), 29-40.

Schipper, K. (2003). Principles-based accounting standards. Accounting Horizons, 17(1), 61-72.

Shackelford, D. A., \& Shevlin, T. (2001). Empirical tax research in accounting. Journal of Accounting \& Economics, 31(September), 321-387.

Sunder, S. (2009). IFRS and the Accounting Consensus. Accounting Horizons, 23(1), 101-111.

Watts, R. L. (2003a). Conservatism in Accounting Part I: Explanations and Implications. Accounting Horizons, 17(3), 207-221.

Watts, R. L. (2003b). Conservatism in Accounting Part II: Evidence and Research Opportunities. Accounting Horizons, 17(4), 287-301. 